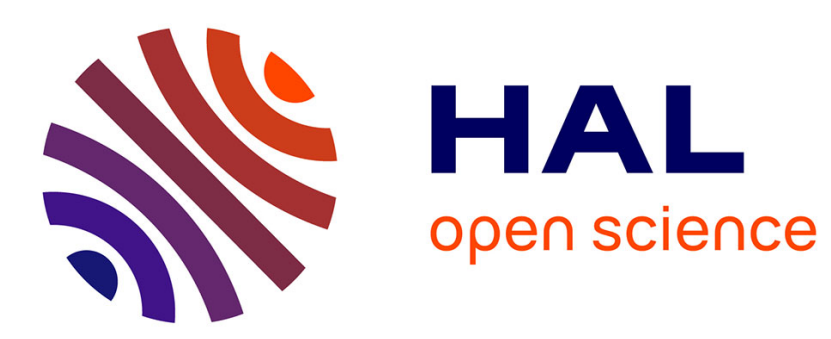

\title{
Who are the European experts? Profiles, trajectories and expert 'careers' of the European Commission
}

Cécile Robert

\section{To cite this version:}

Cécile Robert. Who are the European experts? Profiles, trajectories and expert 'careers' of the European Commission. French Politics, 2010, 8 (3), pp.248-274. 10.1057/fp.2010.13 . halshs-00536024

\section{HAL Id: halshs-00536024 \\ https://shs.hal.science/halshs-00536024}

Submitted on 10 Dec 2020

HAL is a multi-disciplinary open access archive for the deposit and dissemination of scientific research documents, whether they are published or not. The documents may come from teaching and research institutions in France or abroad, or from public or private research centers.
L'archive ouverte pluridisciplinaire HAL, est destinée au dépôt et à la diffusion de documents scientifiques de niveau recherche, publiés ou non, émanant des établissements d'enseignement et de recherche français ou étrangers, des laboratoires publics ou privés. 


\title{
Who are the European experts and on what grounds? Profiles, trajectories and expert "careers" of the European Commission
}

\author{
Cécile Robert \\ Institut d'Etudes Politiques - Université de Lyon \\ Laboratoire Triangle
}

\section{Introduction}

The groups of experts of the European Commission have been, until recently, among the least visible authorities of the government of Europe. Unlike the working groups of the Council (gathering representatives of the Member States and intergovernmental negotiations), or comitology committees (consisting of officials from Member States assisting the Commission in its executive functions), these authorities are solely accountable to the communautary administration (de Maillard, Robert, 2008). Focussed on its initiative work, and composed of external actors with various statuses, these groups have strictly consultative power, which they exert in as crucial as often little publicised a phase of the European decision-making process. Approximately one thousand in number, they have rarely attracted the attention of the media, apart from a few notable exceptions, such as that for instance of the Sapir group (Peuziat, 2005).

Still, last Spring, they barged into the press room of the communautary administration during highly publicised heated exchanges between certain interest groups and the communautary administration. The NGO Corporate UE Observatory, now famous for some tens years, for its crusades against the power of the industry lobbies in the European political system, indeed produced on 25 March 2008 a report suggestively entitled "Culture of secrecy and companies' domination - a study of the composition and of the transparency of the Expert Groups in the European Commission" (Vassalos, 2008). Published by the ALTER EU network (Alliance for Lobbying Transparency and Ethics Regulation) which they are part of, the document was founded upon the analysis of the composition of some forty groups. It denounced simultaneously the opaque operation of these authorities and the - overwhelming - place which they were supposed to secure to the representatives of the industry, enabling the latter to reorientate discreetly as well as efficiently the European decision-making processes in their favour. If it took part in now well-known mobilisations around issues relative to transparency and the relationships between the Commission and the interest groups, it also echoed repeated complaints of the Parliament regarding the scarcity of information available on the expert groups. The attack was perceived as sufficiently significant to trigger a response from the Commission the following day via its lady-speaker, Valérie Rampi, who came back to the efforts made in terms of transparency, and especially the "balanced" character to guarantee the independent expertise called upon within the framework of the groups.

These hefty exchanges underline the issues of the social properties of the experts, and more generally of the actors forming this "European" civil society associated, according to different modalities, with the EU government, issues which are hence raised indirectly. If 
such perspective has long remained a blind angle for political and mediatic discourses, it has also been hardly tackled in the academic literature (Michel, 2007). The first works dedicated to the Expert Groups have indeed rather suggested a macroscopic approach of these authorities, centred on the "functions" fulfilled by the latter within the European institutional system (Larsson, 2003 ; Larsson and Murk, 2007). Finer sociology of these actors seems however indispensable to this type of analysis, since it appears difficult to consider the political strategies conducted within or via these groups, without paying attention to the social resources held by their members and which make them possible. Besides, when they became interested in the composition of the expert groups, the works have focused on the most visible statuses of these actors, adopting the categories mobilised by the administration itself for describing them (academics, government officials, scientists, parties to negotiations, etc.). Although they can provide, as can be seen below, a set of useful information to fathom the heterogeneity, under certain aspects, of this population (Gornitzka and Sverdrup, 2008a, 2008b), these elements still mask, as can be seen below, the fact that these actors share a collection of common properties.

The purpose of this paper is precisely to understand not only who the European experts are, but also on what grounds. Analysing the selection and self-promotion processes of experts indeed enables to go beyond the opposition between frozen and essentialist visions of expertise which are meant to be the exclusive attribute of a category of actors, i.e. the most powerful economic interests, or, conversely, the scientific community, for observing the intricacies of such a stand. Relying upon quantitative and, especially, qualitative data relative to the composition and operation modalities of the expert groups (see text box below), this text thus aims to identify the resources and the practices conditioning access and success in these functions. The idea, by so doing, is to better grasp how the experts' authority can get the upper hand in the communautary arena, and under what conditions it may be exerted.

In this perspective, this contribution first of all wishes to provide an overview of the space of European expertise: highlighting the political usages of the groups thus enables to explain the privileged recruitment of experts in certain categories of practitioners («academics », members of interest groups, national civil servants, etc.) (I) These political usages also contribute to promoting particular resources and practices, leading to analyse the properties shared by the experts, in spite of their apparent heterogeneity. (II) A number of these properties are moreover acquired in the communautary space, inviting to take a closer look at the way these expertise functions are fulfilled in professional trajectories associated with the UE institutions. (III)

\section{Text box no 1: investigations and data on the Expert Groups}

The expert groups constitute, in spite of recent reforms, a field hardly accessible to external observers. The constitution and the leadership of expert groups have indeed long been considered as activities only governed by the internal life of the Commission and which said Commission was consequently not particularly accountable to the outside world. Since these activities are exerted in much decentralised fashion, most often at units, and on the basis of very flexible administrative rules, the memory of these activities often existed only in departments, and in very disparate forms. It was only recently, in 2005, further to a series of parliamentary interpellations, and along the line of the administrative reforms initiated by the White Book on Governance (European Commission, 2001b), that a registry of these groups was prepared and made public (http://ec.europa.eu/transparency/regexpert/index.cfm). For the reasons just mentioned above, the work instrument provided by said registry is not always reliable and contains lacunar data. Within the framework of our investigation, we have had the opportunity 
to discover that numerous groups were listed therein, whereas others, mentioned in the registry, did not appear to exist actually or to have been dissolved for a long time. Similarly, the pieces of information relative to their compositions (per great types of actors) and operations (frequency of the meetings, objectives assigned) are succinct and inaccurate: by way of example, a group listed as temporary will have, more often than not, been in existence for a long time and met more frequently than a so-called permanent group. Finally, the registry does not contain systematically, far from it, information on the identity of the members of the groups. Only those whose creation originated from a formal decision of the Commission, adopted by the College, are subjected to this obligation. In particular for these reasons, to which is added the overabundant number of existing groups - often estimated as more than 1200, among which 986 were listed in March 2009 on the site of the Commission-, this research relies on qualitative data to a vast extent.

The investigation hence rests on a little more than thirty groups, registered in different Directorates-general and departments: General Secretaryship; DG for "Employment, social affairs and equality of fair opportunity"; DG for "Transports and energy"; DG for "Education and culture"; DG for "Research"; DG for "Justice, freedom and security" (interviews conducted by Anne-Cécile Douillet and Jacques de Maillard); DG for "Agriculture and rural development" (interviews conducted by Marie Hrabanski); Group of the political advisers and Office of the European political advisers (interviews conducted with Oliver Baisnée).

The data are formed after looking up administrative sources and mainly on the basis of semidirective interviews (around sixty) with the civil servants in charge of the composition and of the follow-up of the groups on the one hand, and with experts who are members of these groups on the other hand. 


\section{The structuring logics of the European expertise space: when expertise absorbs consultation}

In this section, we would like to come back to the great structuring logics of the European expertise space. We shall first of all touch on the rules governing the creation of the expert groups, before going in more substantial detail into the definition of the expertise underlying said groups. The recruitment and composition strategies of the groups are indeed guided very directly by a "consultative" design of said expertise: it is designed simultaneously as a pre-negotiation time and as the means of collecting elements useful to the decision-making process.

Initiated by the publication of the White Book on Governance, the recent reforms of the expert groups have given rise to hefty reactions in the Departments of the Commission. The groups are indeed perceived as one of the instruments and guarantors of the autonomy of the European administration when exercising its power of initiative. This perception has somehow comforted the idea that the creation of an expert group should remain a little formalised practice, an instrument whose accurate configuration would be determined on a case to case basis, by the various agents and in relation to their needs. This very flexible institutional frame applies moreover to a very little centralised practice - the vast majority of the groups is managed at the lowest hierarchical level, that of the units-, thus authorising great lability of this administrative definition of expertise. As can be seen in the following text box, the only formal common feature of the "Expert Groups" is a strict consultative function, and the fact that they consist of people statutorily "external" to the Commission when recruited.

\section{Text box $\mathrm{n}^{\circ}$ 2: The administrative framework of the expert groups}

In the administrative texts governing the operation thereof (European Commission 2002, 2005), the expert groups are mainly considered through their function and especially their absence of decision-making power; these are purely consultative authorities enabling to feed the initiative work of the European Commission. As such, they are defined in opposition to the comitology committees (mentioned in the introduction), to the social dialogue committees (which may groove propositions for the Council), and to the so-called "mixed" entities (derived from international agreements and designed for controlling the implementation thereof).

According to the words of the Secretaryship-General of the Commission: "A group of experts may be defined as a consultative entity consisting of national and/or private sector experts, set up by the Commission for advising purposes. A group of experts is essentially responsible for assisting the Commission and its departments in the preparation of the legislative bills and of the political initiative (right of initiative of the Commission) as well as in its supervision and coordination or cooperation tasks with the Member States. A group of experts may be permanent or temporary. The members of a group of experts are not remunerated but their expenses are refunded by the Commission ${ }^{l}$.

\footnotetext{
${ }^{1}$ Page of the secretaryship-general http://ec.europa.eu/transparency/regexpert/index.cfm, visited on 1 September 2008 .
} 
If some of them (estimated at fewer than $10 \%$ of the groups in activity) may be subjected to a formal decision of the College, most of them are appointed by the departments, with the (quasi systematic) agreement of the Secretaryship-General. This distinction, no more than that between permanent groups (created by a formal act or over 5 years) and temporary groups, is not reflected by specific recruitment rules and practices.

It should be mentioned finally, as can be seen below, that the experts belonging to national administrations or certain interest groups, may, under certain configurations, be designated by their own organisations and institutions. The departments of the Commission then form a typical group, specifying the administrations and groups approached to, by requesting them to send, according to the subjects on the agenda, the person whom they deem the most competent for this particular point.

This flimsy administrative framework and the ad hoc character of the composition of these groups are in line with one of the principles guiding these practices: the management, during the expertise procedures, of consultation logics of the "interested parties". In other words, if each of the expert groups epitomises this combination according to various modalities and degrees, their common feature is to claim double legitimacy for their expertise: that of a specialised know-how intended for enlightening the decision, and that of a viewpoint representing the publics concerned by said decision. The presentation made by the Commission on the Europa website is quite clear about that: "The composition of a group varies according to the type and the field of application of the expertise sought after. The score of knowledge provided to the Commission should not only be excellent from a scientific viewpoint, it should also be in keeping with practical, legal, social, economic and environmental considerations; consequently, numerous groups include not only scientists but also executives from the public and private sectors and other similar actors ${ }^{2}$."

This definition of expertise becomes meaningful in the light of the political issues associated with this form of consultation (Robert 2008, 2009). Since 2000, it has been the subject matter of an institutional discourse which intends to use expert groups as a means to demonstrate "the openness of the Commission to civil society" and the democratic character of its decision-making processes. If the argument is not new, it has benefited from specific formatting and increasing publicising since the White Book on Governance was published (European Commission, 2001b). Several documents (European Commission, 2001a, 2002) have contributed to formalising a definition of expertise explicitly asserted as representative, with reference to two main issues: the necessity not to reduce it to the conventional scientific knowledge corpus and to enable it to take other "concerns" on board, i.e. other "points of view" to be "socially robust"; the possibility of turning the very process of expertise elaboration into a privileged moment for restoring trust with the civil society, providing that the latter is more systematically integrated thereto.

These symbolic issues - taken "target" actors of the European policies into account, multifaceted expertise - of the composition of the groups also refer to practical concerns. For the officials of the Commission, forming an expert group thus often aims to collect information capable of feeding the wording work of the Commission bills and, in particular, to provide better knowledge of the fields of intervention.

2 Page of the secretaryship-general http://ec.europa.eu/transparency/regexpert/index.cfm, visited on 1 September 2008. 
However, regardless whether taking stock of the existing provisions in the national legislations, surveying the socio-economic situation of a given category of population in the different Member States, or still drawing conclusions on the different manufacturing methods of an industrial plant, setting up such a consultation is also, intrinsically, a means, for Euroofficials, for testing and working on the social and political acceptability of their initiatives. By authorising forms of concertation and consultation beforehand, discussing the Commission bills in these groups enables to anticipate oppositions, to integrate certain constraints by reshaping said bills, finally to track the modalities of their application on the national fields. The exchanges and the opinions voices in the group are thus often presented as arguments meant to convince possible interlocutors (Parliament, Council, other Member States, interest groups), in particular moreover when these same interlocutors are "represented" within the expert groups. Besides, the obligation imposed to the departments since 2004 to provide, for each act of the Commission, an impact study ${ }^{3}$ has encouraged further the implementation of consultations with the different actors affected, for which the framework of the groups is sometimes used. For their own part, the "experts" themselves besiege these authorities for partially similar reasons. While bearing in mind that these logics are diverse, and that they are individual as well as institutional and collective, they also tend to turn these groups into a place for pre-negotiation. For the experts interviewed within the framework of this investigation, the purpose is in particular to make oneself heard very early in the reflection process of the Commission, to better understand the positions of the competing organisations or of the institutional partners, to make use of, possibly, the presence of representatives from Member States, for seeking commitments, for highlighting gaps in the implementation of any European guideline, etc.

Thus, regardless of the respective political or technique portions in the expertise expected, each recruitment is thought of and performed as choosing a representative as well as an expert. In other words, every expert is considered - regardless whether he/she and the recruiters like it or not - as a potential representative. This specific representation of the expertise leads consequently to cease to consider experts as top-rank specialists in the same discipline: said expert knowledge is neither a prerequisite nor a widely shared property. The "knowledge" or the skill of expert sought after in this procedure, far from being limited to academic titles, are closely dependent on the expert belonging to different national, professional or activist "collective bodies". Not only this belonging enables to promote this qualification, but it can even postulate it, in replacement thereof.

To give but one example, an illustration can be found in the grounds for which the members of the high level group on social integration of the ethnic minorities and their full participation to the labour market ${ }^{4}$ are officially recruited and introduced on the site of the Commission. Thus Louis Schweitzer was appointed on the basis of his responsibilities in the "Halde" (French High Authority against Discriminations and for Equality); Lee Jasper as Councillor for ethnic issues to the Mayor of London; Jarmila Balážová, because she belongs to the Rom community and presents in particular a Tchekian radio programme dedicated to them; or still Rita Süssmuth, former president of the Bundestag, and former Minister of Family, of Feminine Condition, of Youth and Health, on grounds in particular of her participation to different types of (national and international) Commission on migratory issues.

3 Associated with the "better regulation" reform initiated in the Commission.

4 Regarding the status of the group, refer to JO L.21 of 25/01/06. Regarding an introduction of its members and of some of its activities, refer to the dedicated webpage on the Europa site:

http://ec.europa.eu/employment_social/fundamental_rights/policy/hlgph_en.htm. 
Finally, if these belongings sometimes replace academic diplomas, they may conversely devalue a candidacy, let alone bar recruitment altogether. An emblematic example is provided by the national belonging, which in order to secure the group the required representativity at the geographical level, may prove, in relation to the configurations, a considerable asset or handicap. All the more so since this representativity tends to integrate weighting forms, such as that which consists in considering that the, although necessary, "representation" of the countries from Central and Oriental Europe, can be secured by a small number, if not one of them only.

"A geographical balance is still necessary, i.e. having Northern Member States only is not acceptable, Scandinavian countries are known to possess very close legal systems, so if we do not have a representative from each of the three countries, it is not critical, but we must have at least one Scandinavian ... A Common Law is necessary, the new Member States must participate; we cannot have the ten of them, but at least two or three ... There are States which are still powerful in terms of votes in the Council, whereas if Lithuania does not agree, well you know how it is ..."

This unique design of the qualification desired in this procedure, as well as the political usages expected therefrom finally provide elements for understanding the diversity and the heterogeneity, at least apparent, of the expert population. Far from being a unique model, the only expert groups studied within the framework of this investigation have very diverse configurations, adjusted in particular to the political usages intended by the departments when creating them. They are distributed around different poles, corresponding to partially differentiated recruitment logics. A first axis consists of an opposition, conventional in works on expertise, between groups expected to be true proposal forces, and authorities playing a more symbolic role, either due to their simple existence, or because they validate and vouch for ideas and projects prepared somewhere else. Along a second axis, the groups are apportioned according to the nature of issues examined therein: from the more «technical» ones (requiring specific knowledge, less legible immediately in political terms) to issues most explicitly centred on determining what is feasible politically (prior consultation of the representatives from national administrations and interest groups to determine the supports and oppositions to a given project) ${ }^{6}$.

Groups may be positioned in each of these quadrants (bearing in mind that a number of groups may, relative to the contexts, slide from one quadrant to another). As regards groups less associated with the preparation of the bills initiated by the Commission than to the legitimisation thereof, an authority such as the Michlaski group, formed under Romano Prodi's presidency and working with the group of the political advisers to "demonstrate the Commission's interest" in issues relating to the cultural and spiritual dimension of Europe, may be mentioned as closer to the "political" pole. Closer to the technical pole, one may think for instance of a series of groups composed in particular of academics and whose executives in the DG for "Employment" mention the "theorising" and "formalising" role of the initiative engaged by the Commission in a given field.

5 Interview with an official of the DG for JFS, April 2008.

6 The purpose here is obviously not to oppose technique and policy as if it were possible to distinguish among various tight categories, in reality, of "political" or "technical" issues: these qualifications refer less to objects than to the way they are treated and prepared at certain moments of the decision-making process, which means that the same stake and hence the same group may move along this axis as they are treated. 
Close to the decision, but still in the "technical" pole, we have, involved early in the writing process of the bills, authorities like this group of experts composed of a few specialists from the public and private sectors for advising the DG for "Transport and energy" on the methodology of investigations into accidentology. As for the political side, we shall note for instance groups composed of representatives from national administrations for examining with the DG for "Justice, freedom and security" the opportunity of harmonising the national legal provisions regarding "patrimonial effects of marriage".

Highlighting the polarities structuring the space of European expertise then enables to understand why the members of these authorities are mainly recruited in three great "categories" (see tables below) : the academic world, the national administrations of the 27 Member States, and the "organised civil society" (here covering the organisations representing public and/or economic interests with European institutions).

Table ${ }^{\circ} 1$ : Participation in the expert groups of the Commission per categories of actors

\begin{tabular}{|l|l|l|}
\hline $\begin{array}{l}\text { "Categories" of actors who are } \\
\text { members of the expert groups }\end{array}$ & $\begin{array}{l}\text { Number of expert groups in } \\
\text { which the category is present }\end{array}$ & $\begin{array}{l}\text { In proportion to the number } \\
\text { of expert groups listed in the } \\
\text { registry } \\
\text { (N = 1237) }\end{array}$ \\
\hline National administrations & 864 & $69.8 \%$ \\
\hline Competent national authorities & 422 & $34.1 \%$ \\
\hline Academics/Scientists & 412 & $33.3 \%$ \\
\hline Industry/ Companies & 352 & $28.5 \%$ \\
\hline NGOs & 207 & $16.7 \%$ \\
\hline Professionals & 157 & $12.7 \%$ \\
\hline Social partners/ Unions & 146 & $11.8 \%$ \\
\hline Regional and local authorities & 100 & $8.1 \%$ \\
\hline Consumers & 96 & $7.8 \%$ \\
\hline International organisations & 27 & $2.2 \%$ \\
\hline
\end{tabular}

Table n'2: Main "configurations" of the expert groups of the Commission

\begin{tabular}{|l|l|}
\hline Types of composition of the groups & $\begin{array}{l}\text { In proportion to the number of expert groups } \\
\text { listed in the registry }\end{array}$ \\
\hline National administrations & $26 \%$ \\
\hline $\begin{array}{l}\text { National administrations and competent national } \\
\text { authorities }\end{array}$ & $11 \%$ \\
\hline Competent national authorities & $6 \%$ \\
\hline Scientists & $5 \%$ \\
\hline NGOs, social partners, industry and consumers & $3 \%$ \\
\hline Industries & $2 \%$ \\
\hline $\begin{array}{l}\text { National administrations and competent national } \\
\text { authorities and industries }\end{array}$ & $2 \%$ \\
\hline $\begin{array}{l}\text { National administrations and local and regional } \\
\text { governments }\end{array}$ & $2 \%$ \\
\hline National administrations and scientists & $2 \%$ \\
\hline Scientists and industries & $1 \%$ \\
\hline Sub-total & $61 \%$ \\
\hline
\end{tabular}

Source: from Gornitzka and Sverdrup, 2008a 
*: The data used here are extracted from the on-line registry of the Commission on the site of the general secretaryship. On this basis, the researchers have simply performed two types of calculation: for each "category" the number of groups in which it was represented; the identification of "types" of group composition. The "categories" used are those wherein the departments are accountable for the identity of "their" experts.

**: Inasmuch as the registry does not specify which proportion of each category forms the group, table ${ }^{\circ} 1$ does not make any difference between the groups where the category is represented by one expert only and the groups composed almost exclusively of said category.

If reading the expertise in these categories advantageously provides a first picture of the European expertise space, it nevertheless raises several issues. In addition to the poor reliability of the data available on this on line registry (no updates, gaps, etc.), the categories are unfortunately neither homogeneous nor tight: by way of example the "academics" are thus classed apart from the "members of national administrations" whereas in a number of Member States both "statuses" go hand in hand; they are also differentiated from the "scientists", a designation covering in the registry actors coming from public research as well as the R\&D departments of companies. But especially, by prompting to differentiate and often to choose between the multiple attributes ascribed to these experts, such reading tends to leave aside the properties shared by said experts, among which their multipositionality. It is precisely that aspect which we would like to consider now. 


\section{Social properties of the experts and resources promoted in the space of European expertise}

If the design of expertise mentioned previously follows the principle of diversifying the statuses and profiles granting access to the expert's positions, it also contributes, for the same reasons, to building the expertise function in these groups as a particular form of representation. It thus tends to appoint experts among craftsmen and compromise facilitators, which has effects on the importance given to certain social practices and properties. If the latter do not constitute, all of them and systematically, a prerequisite for an actor to become an expert, they seem indeed to strongly condition his/her success in this role and his/her legitimacy in the group. And if still in doubt, it would pay to leave aside a quantitative morphologic analysis for probing certain groups or benefit from interviews the better to perceive this type of issue which is otherwise trickier to fathom.

\section{International openness}

A first set of properties shown and promoted in the expert groups refer to "international openness" of the latter. On this aspect, as on a number of others, the logics operating in the expertise space fall in line with those traceable in other "communautary circles", like Euroofficials (Georgakakis, de Lassalle, 2007), members of the European parliament (Beauvallet, Michon in this same book) or still union activists of the CES studied by Anne-Catherine Wagner (Wagner, 2004). As one of our interviewees puts it quite clearly: "The rule of the game is to endeavour not to understand the problems from a national viewpoint, which is very difficult. The ideal choice is a person born in Sweden, having studied in Spain and worked in Germany." (Interview with a member of the group of the political advisers, July 2005. ) The promotion of these resources thus takes on two complementary forms, referring not only to practical skills - mastering speaking languages and especially English, but also to a form of symbolic credit associated with the international trajectories and the "predispositions" they are meant to induce.

Often justified functionally, linguistic skills, and particularly fluency in English, are of paramount importance. The investigation conducted further to the adhesion of the countries from central and oriental Europe highlights one of the major effects of the enlargement on the administrative organisation: the now overwhelming domination of English as working language in the European institutions. For the experts, this involves the necessity to speak English during most meetings - only a few groups have interpreting systems available selectively or work within Directorates-General wishing to maintain a multilingual meeting framework -, but also the obligation of reading and writing in that language. Being a polyglot, and more specifically being relatively fluent in English, may constitute more or less explicit recruitment criteria. If this "rule" is mentioned by most Euro-officials interrogated, often matter-of-factly, so is the case of the experts: several people interviewed within the framework of this investigation, in particular French experts, thought they owed their appointment to their fluency in English and the scarcity of this skill in their own professional environment.

The recruitment system may prevent strict application of this criterion. Such is the case in particular of the groups of so-called governmental experts, which hire staff from nurseries of national officials with variable ability to work in English on a regular basis. However, the 
linguistic resources are almost always a must in practice as an inescapable element for being heard and credible within the group. A contrario, the - rare - situations where the staff cannot express themselves in English are perceived, by the expert affected and by his counterparts, as very handicapping. Such is exactly the case with this member of the group of experts on the sugar channel, a monoglot, Wallon farmer: if the "field" legitimacy acknowledged to him by his counterparts by reason in particular of his status as a farmer allows him to become chairman, he is almost totally cut out from the exchanges during and especially outside the meetings, and cannot partake in the writing process of any document generated by the group.

As illustrated by the latter case, fluency in foreign languages is deep-rooted both in national and social backgrounds. They tend to disadvantage more often than not the representatives from Southern Europe and French-speaking countries. Moreover, according to national contexts, having and acquiring these linguistic skills do not refer to the same profiles and trajectories. The so-called "governmental" expert groups, composed of officials from national administrations, are a particularly striking example thereof, since they gather individuals with relatively similar educations and positions, but extremely different levels of fluency in English. It is mainly when confronted to such configurations that some experts embark on strong-willed self-tuition strategies. Through their endeavours, they demonstrate the unequal, in particular national, situations facing this challenge, but they also bow to the significance they ascribe to this linguistic skill ( "I owe it" to my European counterparts in the group, but it may "prove useful later on"). Apart from this peculiar cases, being a polyglot is often the feature of experts who were raised in multilingual families, then whose university and/or professional trajectories led them to live and work in various countries.

These international experiences reflect various trajectories: from a university cursus comprising a stay financed by the Erasmus program in another Member State, via graduating in prestigious English or American universities, to working in an international environment. They are in particular encountered in positions promoted for other reasons in the space of European expertise: it is first of all the case of the experts originating from the "academic world", that the professional framework predisposes to build and maintain international networks. Among the international experiences put forward particularly by experts and their recruiters there is the belonging to different organisations or international negotiation circles: in addition to the European institutions properly speaking, those which operate under the control of the United Nations, NATO, the OECD expert committees (in particular for the experts originating from national administrations), are mentioned most frequently.

Through these recruitment criteria and the meaning they ascribe thereto, the Euroofficials tend to import and reproduce, in the expertise space, values and hierarchies which prevail more generally in the communautary institutional space. They are hence keen to associate high symbolic, in particular intellectual and moral value with the "international dimension": it would be, in the context of expertise, the guarantor for the open-mindedness of the expert but also for the universality of his knowledge (Robert, 2008b). It is notably in this perspective that comparatist skills (regardless whether formalised in university practice as for compared law, or only postulated by the accumulation of experiments in different national contexts) are particularly promoted: "Because what we are looking for, at this stage, is expertise ... And of course people with many contacts abroad. Because our major problem, here, is the overabundance of superskilled experts, but unable to communicate with other people, let alone with people from other legal systems" (Interview with a member of the GD for JFS, April 2008). 


\section{Embodying neutrality}

As a second type of resources promoting access to positions of expertise, the professional statuses of the actors approached for becoming members of these groups. For Euro-officials indeed, certain of these situations and (professional) trajectories would, more than others, predispose them to show more independence when working as experts. Such a concern refers to the consubstantial ambiguity of the system, and to the political usages expected therefrom. The experts are always associated, to various extents, with one or several spaces (national, professional, activist), which would then be somehow "consulted" via their mediation. But they are also invited, on account of their position as experts, and of the necessary "neutrality" implied, to relinquish, in word as well as deed, to act as "representatives", in the meaning of trustee, for the spaces from which they originate (Robert 2009b). These logics are present everywhere, although at various degrees: so even the national officials, members of the "governmental expert groups" supposedly "do not receive any instructions from their respective government". They provide the expert group with their national expertise in a particular field ${ }^{7}$."

In this peculiar scheme, the presumed autonomy attached to certain positions thus takes on significant value. The idea is to select experts whereof the professional situations would better enable them to keep their distance from possible sponsors or which however may be construed as such outside, thereby strengthening the legitimacy of the group. Different categories of actors benefit from these recruitment logics. One of the directors of the DG for "Employment, social affairs and equality of fair opportunity" thus stresses that his directorate is keen on recruiting former "workmates" - representatives of their national administrations, union organisations before the Commission -, whose "pensioner" situation would guarantee formal autonomy of their judgments: "There is also a pool of independent experts provided by the pensioners, those who worked for an administration, a professional union and then left, are not affiliated thereto any longer, but when they belonged to these circles, they represented them, within the committees, notably comitology, and have demonstrated in this framework an authority, a skill that we wish to use further."."

The same reasoning goes for a second category of experts: the staff of the public university teaching and research. Generally designated as "academics", they are indeed very well represented among the members of the groups of experts ${ }^{9}$, in particular because they are considered as more "independent", by status, than by vocation: "Yes, the Commission often resorts to academic expertise and in particular the Belgian expertise, there are many academics in Belgium who are very independent and on top of that, they are not far away. Consequently, Belgium is an exceptional reservoir of expertise for the Commission. Are academics considered as more independent than the other experts? Certainly so, in particular less linked to particular interests than experts from companies, or administrations, because I forgot to mention the whole expertise from companies and which is quite used by the DG for "Companies" "10."

7 Page of the secretaryship-general http://ec.europa.eu/transparency/regexpert/index.cfm, visited on 1 September 2008.

8 Interview with a member of the DG for Employment, November 2004.

9 According to the registry of the Commission mentioned previously, close to one third of the expert groups would thus include experts belonging to the wider category of the scientists and academics.

10 Interview with one of the former directors of the Prospective Unit, J. Vignon, November 2004. 
The particular credit ascribed to "academics" in the expertise procedures may obviously be explained by the fact that they have accrued, sometimes exclusively, specialised knowhow considered as useful to the decision-making process. Incidentally, the selection of the experts indeed reflects to what extent certain disciplines, more than others, are meant, according to the periods and the departments affected, to involve sound knowledge of governmental affairs: by way of example if lawyers and legal advisers are strongly represented in the groups of the DG for "Justice, freedom and security" and to a lesser extent of the DG for "Employment, social affairs and equality of fair opportunity", one cannot but observe that they have yielded much ground to economists in the groups of the BEPA.

Their selection rests nevertheless significantly on this presumed independence, from private and in particular economic interests, as from national interests, which are just as (if not more) crucial for Euro-officials. This dimension is particularly significant when dealing with expert groups responsible for examining the transposition and application conditions of European guidelines in the Member States (such is the case in particular of numerous groups of the DG for "Employment, social affairs and equality of fair opportunity" and DG for "Justice, freedom and security") or accompanying the coordination systems of the national policies (otherwise called open-ended coordination methods).

"To analyse national transposition measures, somebody independent is required. A person with an academic background, a university law professor, is usually the best choice. (...)When I say independent, I mean independent from the Member States and the Commission ${ }^{11}$.

As shown by the example of the groups formed around the BEPA and the Commission presidency (text box), the academics are particularly well represented in so-called "high level" groups, whose work and composition are meant to be extremely publicised. These profiles of academic experts show moreover similarities with those of the Euro-officials who recruit them: we may mention here common predispositions for international affairs, but also the strong representation, among the European administrative (and political) staff, of university postgraduates and doctors (Beauvallet, Michon in this same book; Georgakakis, de Lassalle, 2007). More generally, the significant presence of actors originating from the academic world within the expert groups may thus be understood as one of the manifestations of the close links which have been woven, since the Fifties, between the European institutional elites and the researchers specialised in the communautary construction in different disciplines (law, economy, political science).

11 Interview with a member of the DG for JFS, October 2006. 
Text box no4: the weight of the academic capital, the example of the high level groups of the GOPA and of the BEPA

The weight of the academic capital can be observed most particularly in the case of the Bureau of European Policy Adviser. The BEPA is an authority enjoying the status of a DirectorateGeneral, directly accountable to President Barroso. It inherited from the GOPA (for Group of Political Advisers) created when Romano Prodi was President and, previously, from the prospective unit - created by Roy Jenkins and quite visible below both mandates of Jacques Delors. Under the current and immediately preceding mandates, these structures have generated and led expert groups whereof certain have won particular renown, like the Sapir group (Peuziat, 2005). All the members of the three expert groups associated with the Bureau of European Policy Advisers ( "political analysis group", "economic analysis group", "society analysis group") fulfil or have fulfilled teaching and research positions in university, which was also the case of the previous groups and structures: six members out of seven forming the Sapir group are thus introduced as professors. These three groups are accountable to "special advisers", working within the BEPA during the presidential mandate, which also originate from the academic world. The weight of the academic capital is not the exclusivity of the BEPA and can be observed in most groups benefiting from great visibility: let us quote for instance the "Kok" task force after the name of the former Dutch Prime Minister, Wim Kok, responsible for preparing in 2003 a report on the employment policies in Europe, and whereof five of the eight members are university professors.

\section{An induced property: multipositionality}

More careful examination of the careers and profiles of these academic experts highlights a third property promoted in the space of European expertise: multipositionality. In addition to their university titles and functions, all the experts mentioned previously indeed hold concurrently positions in other social and professional spaces.

Such is the case for instance of the members of the Sapir group, which evolve in the academic world, but also in those of high-level public service and consulting. The same goes for the academics who are members of the Kok group, who follow both political careers and high-level national or European public service careers (Maria Joao Rodriguez) or as a consultant for the public and private sectors (Carlo Dell'Aringa).

One may still mention the profile of both special advisers of the "political analysis group" accountable to the BEPA. Loukas Tsoukalis holds a university chair, Jean Monnet, and is a professor in the University of Athens and in the College of Bruges, he has been an ambassador and has fulfilled functions as a special adviser for several Greek governments, and he has also been involved in the activities of a consulting firm working for the European Union. As for Dusan Sidjanski, he is the founder and the former director of the Department of political science in the university of Geneva: known for his Pro-European political commitment and the positions he has fulfilled on the federalist scene, he has finally exerted consulting activities for different international organisations.

This multipositionality is moreover not an exclusive property of the members of the "high level" groups; its forms vary in relation to the sectors and administrative segments with which the experts are connected: law professors, lawyers and activists for human rights in the DG for "Justice, freedom, security"; teacher researcher, going back and forth between consulting activities and secondment in the central administration of the DG for "Employment, social affairs and equality of fair opportunity"; academic capitals in political science and political experiences versus academic capitals in economy and experiences gleaned in the private sector in the BEPA, etc. 
The "social surface" and the "magnitude" associated with this type of profiles holding concurrently different types of capitals are obviously in line with the fact that multipositionality, that is to say sought after and promoted ${ }^{12}$. It is a good indicator of the magnitude of the social resources available to the expert and which he may now activate possibly to provide enhanced expertise and to the greatest satisfaction of his sponsors. This may explain why this property more particularly, although non exclusively, characterised the members of the so-called high-level groups mentioned previously. As for Lord Simon, one of the members of the Strauss-Kahn group ${ }^{13}$, the lady official responsible for following up the group thus justified this choice: "Lord Simon had been part of several groups, during the Delors era, he was chairman of British Petroleum, he was a member of parliament, he had a way with words, he had good understanding of economic and social phenomena, it was perfect, for a expert practitioner's role ${ }^{14}$."

The preference in favour of these multipositioned experts' profiles finds here additional justifications. As regards specifically the academic experts, it touches on the idea that good experts must precisely break free from academic standards to meet the expectations of the Commission. The transgression, imposed by practical expertise, of the rules of the scientific work is one of the fundamental characteristics of this activity (Robert, 2008). Distrust against university professors unable or not willing to relinquish an academic posture seems however particularly strong and widespread: "There is also here a great distrust against purely academic staff, I was recruited far more because of my experience in seeking relationships with authorities for the promoting research, rather than because of my being a professor. The preconceived idea is that a professor is rigid, does not understand the expectations of a policy maker, is always concerned about his own image and communication, and what he does in the Commission is not so important, and this feeling is so systematic. And the truth is that anyone having dealt with academics will second that opinion ${ }^{15}$."

This representation of the academic "conservatisms" would thus explain the privileged choice in favour of experts with regular experiences outside university. As underlined for instance by that lady official of the DG for "Justice, freedom and security" in charge of a group composed of law professors: "Most of them had worked with public authorities so they were aware of the expectations, so they knew that what they were writing had to be relevant to build a policy of prevention, how this knowledge could be relevant for politicians. They knew it was different from an academic circle where they just have to talk about their research. [...] Some had already worked with public authorities, as counsellors for institutes or running institutes set up by public institutions... or for international organisations (UN) I noticed that those who had this background were more [accurate]. They are not pure academics ${ }^{16}$. »

\footnotetext{
12 For an illustration of this opinion on a group of experts at European level (Peuziat, 2005), for a reflection on the issues of multipositionality in an expertise context (Memmi, 1989).

13 The Strauss-Kahn group, also designated as the "Round Table: a sustainable project for European society" has been set up with the group of the political advisers accountable to the president of the Commission (GOPA). It has been entrusted with a reflection of the promotion modalities of the economic, social and environmental dimensions of the sustainable development. It operated in 2003.

14 Interview with a former member of the group of the political advisers, July 2005.

15 Interview with a member of the DG for Agriculture and rural development, July 2005, (conducted by C. Robert).

16 Interview with a member of the DG for JFS responsible for a group of experts, April 2008.
} 
More generally multipositionality is finally justified in that actors having occupied several positions in contrasted social spaces, would be, more than others, predisposed to break away from their original circles, and to demonstrate the autonomy necessary to an expert position.

A little like transnational trajectories are associated with open-mindedness, it is thus supposed to guarantee a kind of neutrality and a certain "sense of compromise ". As shown by the expert figures mentioned above, these representations seem to echo certain profiles whose multipositionality goes hand in hand with strong investment in European subjects, just like these experts who still navigate between teaching, consulting and administrative functions but always around the communautary institutions. The distance they maintain towards their original circles thus reflects their spatial closeness with the European institutions, as can be observed in the following section. 


\section{European trajectories and expert careers: the Expert Groups in the European institutional space}

Regardless of the various qualifications for which they are invited to join the groups associated with the Commission, the European experts thus share a number of properties. Liable to promote viewpoints independent from their original circles (and consequently their supposed expertise and representativity), they also converge in their common relation to the European institutional space. When observing the trajectories of experts, it appears thus that the latter are recruited predominantly among colleagues and/or "partners" of the European institutions. Moreover, there are forms of "European careers", either by accumulating expert positions with time, or by reaching other positions in relation to, possibly inside, the Commission.

\section{"Regular visitors » of the European institutions}

Among the resources shared by members of the expert groups, familiarity of the latter with the European institutions and prior to being appointed as an expert is surely one of the most common. Such familiarity may be the product of various professional or activist experiences, and diversely put forward by Euro-officials as well as by their experts.

At first view, this familiarity takes on the shape of an often far-reaching knowledge of the operation of the European institutions and of the communautary policies affected by the subject matter of the expertise. European administrators and experts agree to consider that expertise is only useful if taking into consideration the constraints and possibilities of the sponsor to formulate concrete and defendable propositions. The idea is on the one hand to master the communautary actions and systems existing in the sector affected, as well as the apportionment of skills, the legal bases and the decision-making procedures governing said sector. The purpose on the other hand is to have relatively accurate pictures of the positions of the main actors on the subjects affected, of the major cleavage lines and of the possible power struggles, to fathom in particular the margins for manœuvre of the departments asking for the expertise.

In certain configurations of expert groups extremely close to consulting interest groups, the organisations will thus send, when they can, two experts: one being an activist belonging to the organisation or its components, representing technique expertise, and the other, a wage-earner in the Brussels office of the association, used to regular contacts with the European institutions, and often a university postgraduate on communautary issues. Thus, the COFACE (Confederation of the family organisations of the European Union) is represented in the high level expert group on drawback by a wage-earner member covering this sector in the Brussels office, and by the director of one of its member organisations, a Belgian association, based in Brussels, of families of polyhandicapped children. the latter is besides not deprived of communautary skills. Due to the dynamism of his association but also to his geographic proximity with the institutions, he has already been associated to the Expert Groups, as soon as created by the Commission, with consultations on handicap.

The acquisition modes of these qualifications, as well as their degree of mastery are various. Most of them however has some, at least theoretical, knowledge of the operation of the UE in their intervention sector. Moreover, the latter is often partially the product of 
experience and is coupled with more practical knowledge of the policies and institutions affected. The existence of collaboration relations, prior to accessing positions of expertise, is indeed a second dimension of the "familiarity" of the experts with the European institutions.

Text box no 5: The importance of "European experiences" for becoming experts The example of the consultative group on the integration of the ethnic minorities

This is what for instance the composition of the "High level consultative group on the integration of the underprivileged ethnic minorities in society and in the labour market" illustrates, already mentioned at the beginning of this chapter. Interrogated on the criteria which have governed the selection of its members, the administrator of the Commission will first of all come back to the eclectism of the members of the group at length, whose interest in the situation of the Rom minority in Europe is mixed, to say the least. It is only when asked about the means used for locating the people affected that he will explain: "we knew the ten of them, because each of them, in their past, had collaborated with the Commission in various contexts ${ }^{17}$." The careers of the experts affected testify besides to the variety of these prior forms of collaboration. The Finnish lady expert, Tarja Summa, presented as a "former mediator for refugees" has fulfilled important functions with the Finnish government during the Finnish presidency of the UE. Ilze Brands Kehris, lady director in Latvia of a centre for human rights has been a member of the management committee of what has become the European agency for fundamental rights. Bashy Quraishy is the Danish president of the European network against racism, which has long maintained close relations with the DG for "Employment, social affairs and equality of fair opportunity". José Manuel Fresno is director general of the Luis Vives Foundation, which promotes the third sector and the social economy in Spain, and which benefits from a financial support granted by the European social fund and strong recognition from the Commission. Jarmila Balážová, a journalist and activist in the Czech Republic for the defence of the Rom minorities is also a close relation of Commissioner Vladimir Spidla. Finally, István Sértö-Radics, presented as the mayor of a small town in Hungary, Uszka, within which the Rom minority would be particularly represented, is also a member of the Committee of the Regions of the European Union.

As illustrated by the example of the "Consultative group on the integration of the ethnic minorities", several situations may be identified. A first type of experience refers to all the forms of temporary contracts offered by the Commission to external operators: commissioned studies, financing via FPRDs, a participation more generally devoted to implementing communautary programmes (structural funds in particular). Such is the case in particular of the experts originating from the "academic" world whereas almost all of them have had prior experiences in contractual research with the European administration. Outside the FPRDs, certain departments, such as the DG for "Employment, social affairs and equality of fair opportunity" and the GD for "Justice, freedom and security" commission studies on a very regular basis, whereof the authors are then appealed to for forming the groups. These cumulated activities with the expertise functions can also be observed at organisations scale. Thus certain interest groups frequently called pun to be part of the groups, the "European civil society", just like the COFACE mentioned previously, are often also beneficiary from communautary funds on grounds of several of their actions, and the privileged interlocutors of the departments within the framework of other modes of consultations (forums, Internetbased consultations, etc.).

17 Interview with a member of the DG for Employment, June 2007. 
In these configurations, the "European capital" which can be the fruit of prior collaborations with the Commission is less personal than collective a resource, accumulated within structures. A logic validated by the recruitment systems of certain expert groups (see text box $\mathrm{n}^{\circ}$ 2) which designate not so much individuals but organisations, leaving the latter in charge of selecting, according to the themes proposed, the expert(s).

A second type of meetings between the Euro-officials and their experts takes place outside the institutions. This may happen at the periphery thereof : via think tanks, and more generally spaces endeavouring to establish relations between the academic world and the European political and administrative elites. These meetings may also take place on other international scenes, such as the OECD committees. Finally, the experts originating from the national administrations have been and are still, for their own part, very often members of the comitology committees in the same field. It is thus frequent that a group of experts composed of national officials includes, totally or partially, a comitology committee, meeting twice the same day in two different configurations.

An economist by training, Marie George is a member of the group of the European control authorities in charge of data protection (or group 29, by the name of the article of the 1995 guideline which gave light thereto). After a brief career in the banking sector then in the INRIA (National Institute for Data-processing and Automation Research), she joined the CNIL (French National Commission for Data-processing and Liberties) in 1979. At the beginning of the 1990s, she was secondment from the CNIL to the Commission between 1990 and 1995 and partook in this framework of the preparation of several important European guidelines for data protection. Back to the CNIL, she was appointed as division head of the European \& International Affairs and Prospective. In parallel during this period, she partook of several groups at international level - Council of Europe, OECD, in particular.

\section{"Expert careers", expertise as a cumulative resource}

If most experts are thus recruited, overwhelmingly, among the professional networks of those calling upon them, there is one European experience which qualifies most particularly their holders to expertise functions: that of having fulfilled this position previously.

"And there is also an unwritten tradition: when we must form a group, we look at the groups formed in the past on the same subject. We ask how they have operated, who is a talented writer and who is not, how they behave in the group, there is a whole formal but also informal process for judging, storing,, accumulating the experience of the groups who have already worked on that subject and for saying, for this particular aspect, that the contribution of that lady was extremely useful. And consequently, that lady will be given a second chance ${ }^{18}$."

As illustrated by this interview abstract, this practice is not alien to the expertise world being highly codified. Adhering to a set of behaviour standards (sense of compromise, relation to political representation) is recognised both as a central skill, by sponsors as well as by the other experts, and rewarded precisely by the possibility of cumulating, sometimes simultaneously but especially successively, expertise positions ${ }^{19}$.

18 Interview with a member of the group of the political advisers, July 2005.

19 Leading to consider Expert Groups such as places for socialisation. Regarding this aspect as well as the contents of these norms, their political issues and the way they contribute to delineate and direct the work of the experts: Robert, 2009b. 
In other words, providing his holder could demonstrate that he masters the "rules of the trade", a past experience as an expert is a self-reproducing capital. The significance ascribed to prior experiences in the recruitment of the experts thus gives weight to these codes of conduct, but it can also be observed through the trajectories of these actors in the space of European expertise.

If most experts are thus recruited, overwhelmingly, among the professional networks of those calling upon them, there is one European experience which qualifies most particularly their holders to expertise functions: that of having fulfilled this position previously.

"And there is also an unwritten tradition here: when we must form a group, we look at the groups formed in the past on the same subject. We ask how they have operated, who is a talented writer and who is not, how they behave in the group, there is a whole formal but also informal process for judging, storing, accumulating the experience of the groups who have already worked on that theme and saying, for this particular aspect, that the contribution of that lady was extremely useful. And consequently, that lady will be given a second chance ${ }^{20}$."

As illustrated besides by this interview abstract, having "being an expert" is a capital self-reproducing the better as its holder could demonstrate that he masters the "rules of the trade". Among the skills associated by the administrators as well as by the experts themselves to the "good" practice of expertise, there is a set of standards of conduct, meant to determine both the quality of the finished product (collective expertise) and the evaluation of the expert, by his sponsors and by his peers.

Without making a detailed presentation thereof ${ }^{21}$, two great types of standards may be mentioned. A first set of prescriptions or expectations concerning the experts is governed by the will to wipe off the links between their positions and the stands they take. Recruited for his/her representativity, possibly on account of his/her belonging to an organisation or an administration, the expert should not act explicitly by "representing" the latter ${ }^{22}$. If the practices of the experts are not insulated, far from it, from an activity representing outside interests, said activity should never be construed as such. It should rather reflect a procedure founded on the objectivity of the scores of knowledge and the neutrality of the participants. The experts are thus invited to clean their acts, by giving up any explicitly political or "national" argument, and by resorting as much as possible to solid grounds and to a technique discourse to state their opinions.

A second type of norms for supposedly regulating the exchanges within the groups is the "sense of compromise" which their members should display. Taking advantage of their familiarity with the communautary political and institutional games, they must not only be able to perceive what is negotiable - within the group, or for the Commission towards the Council and the Parliament -, but also to adjust their positions therein.

20 Interview with a member of the group of the political advisers, July 2005.

21 We may refer on this score to; Robert, 2008b

22 As reminded in particular by the Secretaryship-General regarding the Expert Groups composed of national civil servants: "These experts should not receive instructions from their respective government. They provide the group of experts with their national expertise in a particular field". Page of the secretaryship-general http://ec.europa.eu/transparency/regexpert/index.cfm, visited on 1 September 2008. 
Even more than in other communautary circles, the participants in these expertise procedures are invited to give the priority of a compromise between the members of the group before defending their own opinions ${ }^{23}$.

As stated by a lady administrative office of the Commission: "A good expert is someone who has no strong individual project. [...] to make a group work, nobody should dominate, even if it is the most intelligent person. If [he/she] has very strong convictions, he/she should not be placed in a group of experts." The experts who cannot give in discreetly as soon as the power struggle becomes potentially detrimental to them, will be judged negatively. Those who, by their discourses or by their attitudes, highlight the conflicts of interest and the antagonisms running in the group, stand little chance of being appealed to again.

Promoted within the framework of the expert groups, these conducts and the representations underlying them are besides common to other communautary circles. Such is the case for instance of the technique preparation of the argumentations; of the controlled usage of the reference to national interest, to an explicitly ideological reading of the stakes of public action; or still logics for belittling tensions and avoiding open conflicts, whereof numerous works have observed the pregnancy in the working groups of the Council (Lewis, 2005; Juncos and Pomorska, 2006), the comitology committees (Eichener, 1992; Krapohl, 2003), or still, the members of the European parliament (Beauvallet, Michon in this same volume, and in ours) and the officials of the Commission themselves (Robert, 2005). Through the similarity of the practices expected from the experts with those common in the European institutional space, one understands better why the professional experiences in connection with the European institutions, and most particularly in the expert groups, appear particularly propitious to recruitment. They are indeed as many moments of privileged socialisation (Robert, 2008b), and of learning the "know-how" and the "behaviour" which then promote access and success in the positions of expertise.

The space of expertise thus appears from this viewpoint as a world where the mastery of the "codes", but also the willingness to adhere thereto is rewarded. If the significance granted to previous experiences when recruiting experts substantiates these codes of conduct, it can also be observed through the trajectories of these actors in the space of European expertise. The governing logics seem indeed to favour, for a number of actors, situations when several expert positions are held sometimes simultaneously but especially successively.

As the administrative data relative to the expert groups do not enable to gain knowledge of this phenomenon ${ }^{24}$, it is difficult to have a global view thereof and to measure it precisely.

23 This posture is asserted even in the official production of the institution, as illustrated by one of the recommendations made to the administrators and to their experts in a document prior to the White Book on governance: "Another significant aspect lies in the predisposition to be influenced by the act of participating. Indeed, if the participants only attend the meetings to expose their own viewpoint without being open to the others', there is a considerable waste of important information and the plurality does not translate into learning, but simple positioning." (European Commission , 2001, p. 9)

24 Inasmuch as for the majority of the groups the identities of the experts are not specified and that even for the groups whereof the composition is publicised, the data are not available before 2005 . 
From the sample analysed in this investigation, it seems more than half, often two thirds of, the members of the groups are led to reproduce the experience, and to be approached to participate either in the group succeeding to theirs, or to another authority of the same type. It is not seldom, moreover, that in most cases, these trajectories are already some ten years old at the time of the interview.

As stated for instance by this expert of the DG for "Employment": within the framework of a career where he alternated positions in the public service (public research) and in the Council environment, he partook of projects financed on FPRDs in the Nineties. Via the network formed around these European projects, he was noticed and approached by the departments of the Commission in 2000 for generating a report on the policies against poverty in his country. When three years later, the DG for "Employment" wishes to set up a group of experts capable to follow the developments of an OMC (open method of coordination) in this field, he was to invite to join it. Composed of 27 members, the group replaces in average two members every year: people absent too frequently or not meeting the expectations. Our expert was one of those who stayed on. After three years, the departments chose to keep a group but with a form slightly different, in particular by integrating experts in the recruitment of their peers. $X$ was approached, by the Commission as by several of its former "colleagues", to be part of the new team, wherein he was appointed again in 2007 for three additional years. A few years before retirement as director of a department in a prestigious college, he did not rule out, however, extending his activity as a European expert beyond 2010, in relation to the propositions put to him then ${ }^{25}$.

Among these trajectories during which the functions of expertise follow after one another, certain expert "careers" take on even more specific forms. In the first place, the trajectories may sometimes be much longer and lead certain actors to stick out as inescapable figures in their fields of intervention. This translates frequently by a participation in groups supervised by distinct departments, and, especially, different directorates-general. The possibility for a expert to be recognised and approached beyond his first network of interlocutors in the Commission thus seems to provide quite a reliable indicator of the later longevity of his expert-like career.

Such is the case of Elspeth Guild, a well-known figure for her legal mobilisations on migration issues in Europe. A Professor in the University of Nijmegen in the Netherlands, a member of the CEPS (centre for European policy studies) think tank, she was also a partner in a lawyer's firm (Kingsley Napley in London). She has not only contributed to several FPRDs for the DG for "Research", she has also been an expert one several occasions and, since the beginning in the 90s, for the DG for "Employment" (within the framework of the observatory of the free circulation of workers), but also for the DG for "Justice and Internal Affairs" (now DG for Justice, freedom and security), in particular through the Odysseus network.

In the second place, the experts holding several offices concurrently sometimes know certain forms of promotions. They may involve in particular recruitment in more prestigious groups, due to their visibility and/or their influence.

The economist André Sapir, a professor in the Free University of Brussels, a doctor of the John Hopkins University, also participated in two European think tanks (Bruegel and the CEPR). Jointly with his different academic and counselling activities, he took on, as soon as 1990, expertise functions with the DG for "Economic and financial affairs", from 1990 to 1993 first of all, then from 1995 to 2001.

25 Interview with a member of the network of the independent experts on social inclusion, March 2009. 
Once he had become an economic adviser to the president of the Commission when Romano Prodi was elected, he was appointed in 2002 President of the high level group in charge of reviewing all the economic policies of the UE; the group produced the report entitled «An agenda for a Growing Europe », better known as the Sapir report in 2003. Under Barroso, and for the whole duration of the college, he was president of the group of experts in economy accountable to the BEPA. During the same period in 2005 he was approached to join a high level group composed of recognised economists, and reported to Commissioner J. Potočnik for advising him on the Lisbon strategy in the field of research.

It is also one of the features exhibited by Jean-Michel Eymerei throughout his career as a European expert for which he offered a reflexive analysis in a recent paper (Eymeri-Douzans, 2008). Then a member of the European Institute for Public Administration of Maastricht, to which institutions commissioned research reports on a regular basis, he was "noticed" by the unit of the DG for "Information society", for which he prepared three documents in 1999 . He then took part, always for the same departments, in various juries, conferences, etc. A little later, he was involved in valuer activities for the research projects financed on the FCRD and became a regular collaborator for these missions for the DG for "Research", who entrusted him with complementary expertise missions. These joint activities for the DGs for "Research" and "Information society" notably led in 2003 to his integration into a group of eight experts formed for advising Commissioner Erkki Liikanen in the preparation of the "eEurope Action Plan 2005" which was adopted during the European Council in Seville.

The promotions accessible to these experts may also, and sometimes jointly, be in the form of new responsibilities within the framework of the group. The point was on the one hand to appoint chairpersons for the Expert Groups. These are honorific functions - they also provide access to some kind of notoriety, if only because the groups and the reports are named, once publicised, after the President. They also offer, in a number of cases, leadership resources (order of speakers, determination of the agenda, and preparation of the documents in close collaboration with the secretaryship conducted by the Commission). Jointly or not with these presidency functions, the experts may be integrated, according to different modalities, in the recruitment of their peers: either as informal advisers to the Commission within the framework of peer review procedures, or by forming themselves a network of European counterparts intended for taking over within the group.

A junior researcher in an Institute in Luxemburg, Y has been, since the end in the 1990s, associated with different European projects on the issue of statistical indicators related to social protection. He has written several reports for various international organisations, he has also partaken of two presidencies of the UE regarding these issues as a political adviser and has regularly represented his government in certain governmental authorities. He was then approached at the beginning of the 2000s by the DG for "Employment" which created a new group of experts on social inclusion. At the end of the mandate, the departments wished to see the group replaced with a network of independent experts, they approached Y informally so that he formed with another colleague a network of which it would be the coordinator. Shortly after being accepted, Y was appointed as president of a more selective and more visible group, a task force entrusted with generating a report on children's poverty, addressed to the Commission and the Member-States ${ }^{26}$.

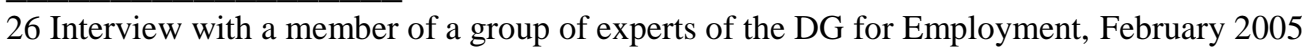


Holding a sociology thesis from the University of New York, a specialist of science sociology, Helga Nowotny has taught in several universities in Europe (Austria, France, Switzerland, Hungary). She has also fulfilled high-level functions within the European Science Foundation since the 1980s, and she was a member of the board of administration of several research institutions in Europe. As of the second half of the 1990s, she has worked as an expert with the DG for "Research" of the Commission, first of all as a valuer for the projects offered for financing on FCRDs. She was then called upon to participate in the expert group entrusted with preparing the guidelines for the "Human and social sciences" section of the same programmes. In 2001, she was offered the presidency of a new expert groups entrusted with reflecting, with academics and industrialists, on the future of the communautary research policy (ESTA then EURAB - European Union Research Advisory Board). She was appointed vice-president of the newly implemented ERC (European Research Council) whose creation had been in particular recommended by the EURAB.

The analysis of these different trajectories thus enables underlining the weight of prior experiences as expert for accessing other functions of the same type. Such trajectories also highlight the contribution of the experts properly speaking to these recruitment logics: among the forms of remuneration and/or of reconversion which are indeed offered to more "regular" experts, recruitment tasks are significant, within the framework of which these "regulars" tend to promote their own types of resources and profiles. When forming their networks for instance, they tend, for various reasons, to approach their former colleagues, who they had met in the Commission. A good example thereof if the testimony of that expert who told that at the end of the mandate of his group, he was approached by no fewer than five members of the group, each embarked on the constitution of a network of experts supposed to succeed thereto. Beyond their similarities, the careers and profiles above-mentioned also lead to remind that all the expert-related experiences are not reproduced with the same efficiency and that the positions they offer depend on other conditions. We have highlighted previously that they were closely related with the capacity of the expert to conform with the unwritten rules governing the individual and collective work in the groups. The future development of his career, as well as the positions which said career will entail, also remain dependant on his own resources - social surface, scientific renown, political and institutional networks, but also professional status, nationality, etc. - and on their adequacy to the different types of groups.

\section{After the expertise: possible reconversions in European careers}

The observation of these trajectories finally leads to mention, more generally, the reconversion modalities of the expertise-related experiences. If the expert's function remains, by definition, a position which is not only provisory but also non-exclusive and nonremunerated, it is however not deprived of effects on the professional careers of those fulfilling such positions. On this score, the example of the experts studied in this investigation enables two first observations to be formulated.

It may first of all be underlined that the forms of "Europeanisation" promoted by expertise may usefully be converted into cash in the experts' origin professional spaces, which explains the investment consented to reach these positions. In addition to the kudos associated with the title, having served as an expert for the European Commission is a golden opportunity for acquiring a collection of practical and symbolic resources. For the applicants in particular, those to whom an expert's position offers one of the first working experiences "in an international environment", the aim may be simultaneously to perfect and to validate 
linguistic skills enabling working in English, far-reaching thin knowledge of a given communautary policy, or still the ability to compare with other national situations and to assert a European viewpoint. Belonging to expert groups also gives access to relational resources, it provides the opportunity to form or consolidate networks, at European scale, of experts and/or foreign professional counterparts, who may prove valuable.

Such is the case for this legal expert whose participation in a group of expert enabled to open new fields of research in compared law: he mentioned in particular access via the group to foreign data, to European colleagues with whom he could set up international research teams, which in turn attracted European financings more easily. For another expert, a senior scientist in a prestigious college, it was the "European dimension" conferred to his $C V$ by his six-year-plus experience in a group of experts, associated with his commitment in research projects financed by the Commission, which contributed to his being appointed at the head of his department.

The establishment of close links with the European institutions promoted by expert's positions has also taken more concrete forms. The most striking cases in this view are those of actors who, after completing one or several mandates, were offered positions in the departments for which they had served as experts. Among the situations encountered during this investigation, on can mention the researchers' positions within the directorates-general, open to "academics" on secondment for one or several years, the national experts' positions offered on secondment to national civil servants, or still the temporary statuses enabling to hire, over various lengths of time, staff members external to the European public service.

This stocklist should also be added the positions offered in structures strongly linked to the Commission: such is the case of the networks of experts financed by calls for tender for a three-year duration, and whereof the contract coordinators and holders are almost always former expert members of the group having paved the way for said network. It is also the case of certain agencies, as for example the European agency for fundamental rights, which also are the heirs of former networks or expert groups and whereof the executive members originate in particular from these groups and networks.

Even if all these trajectories do not lead to the end of a career within the Commission, being an administrator, associated as an expert to the works of the Prospective Unit in the 90s and holding this position since 1999 within the European administration, nevertheless provides a good illustration of the opportunities offered by an expert's experience:

A regional economy and economic geography professor as well as a director of a Research centre in the University of Ancona, $X$ has been approached on several occasions by the Prospective Unit selectively, Shortly after the term of this first contract, she was approached to become a temporary agent in the GOPA [Group of European Political Advisers, inherited from the Prospective Unit, currently BEPA], within the framework of which she has been entrusted in particular with coordinating the activity of high level groups initiated by Romano Prodi (Sapir group, Strauss-Kahn group, etc.). Renewed twice by dispensation, her temporary contract (three years) expired in a context where the structural reorganisation and the change in direction did not offer the same opportunities for her profile. Her contacts and her collaborations with the DG for "Agriculture and rural development" then opened to her the perspective of a new contractual position over several years, wherein she hopes to finish her career $^{27}$.

27 Interview, July 2005 


\section{Conclusion}

Forming a heterogenous world, with blurred contours, the members of the expert groups of the European Commission however share a number of common practices and properties: predispositions to an international environment, academic capitals, experiences in negotiation and sense of compromise. These properties (like the symbolic value conferred thereto by experts) are not so remote from those held and asserted by other populations more central in the European institutional space, just like the members of the European Parliament, the lobbyists and even more perhaps the Euro-officials themselves. This situation is also in line with the fact that, moreover, these groups tend predominantly to recruit actors who already are "intermittent job holders" in the European political space. Finally, the expert's function, although temporary by definition, enables a number of its holders to become "semipermanent staff members" (Georgakakis in this same volume) of the European space. Thus, the recruitment strategies and criteria, like the career logics of the experts, seem to contribute to "bringing experts and recruiters closer", and to transform more generally the space of European expertise into a segment highly structured by, and dependant on, the European institutional space.

These observations underline the significance of an approach by the European government taking the properties of the actors seriously into consideration. As emblems of the new "European governance" (European Commission 2001a, 2001b), the Expert Groups are indeed, throughout the discourse of the institutions and especially of the Commission, portrayed as one of the tools enabling the participation of the "interested parties" in the formulation of public action. Consequently, it supposedly provides the decision makers with the means of a policy all the more efficient and fair so since it is meant to rest on a balanced synthesis of these various points of view. A vision which is rather widely shared by the Brusselian actors, including by the heftiest detractors of the expert groups, such as for example the members of the Alter EU coalition and of the Corporate EU Observatory. Centred on the reduced representation, numerically speaking, of the associative world and of the GNOs, in comparison with that of the industry, their criticisms strengthen, far more than they question, one of the essential postulates driving these government schemes: the idea according to which the gathering, under the same authority, of individuals from voluntarily varied "walks of life" (national, occupational, optionally political) would suffice to guarantee its multifaceted operation. A contrario, the investigation presented in this paper invites, on this score in particular, to caution. It shows first of all that the diversity of the statuses and of the belongings of the actors gathered in the groups does not prevent them at all from also sharing a collection of resources, of experiences, possibly aspirations, which may have the same structuring effect for defining their positions as their most visible identities. It jointly underlines that by reason of the unequal distribution of these resources, crucial for access as well as success in expert's functions, getting a seat at the table of a group will never guarantee an expert to be able to contribute to the construction of the group's opinions and even less to participate with his peers on equal basis ${ }^{28}$.

28 For a perspective of such type on governance: (Padioleau 2000) 
Bibliography

Bourdieu P. (1987), «La délégation et le fétichisme politique », (Delegation and political fetichism) Choses dites, Paris, Minuit

European Commission (2001a), Democratising Expertise and Establishing Scientific Reference System. Report of the Working Group for White Paper on Governance

European Commission (2001b), European governance. A White Paper, Brussels, COM (2001) 428 final

European Commission (2002), Communication sur l'obtention et l'utilisation d'expertise par la Commission - principes et lignes directrices, (Communication on obtaining and using expertise by the Commission - principles and guidelines), C (2002) 713

European Commission (2005), Communication of the Commission. Encadrement des groupes d'experts de la Commission. Règles horizontales et registre public (Managing the expert groups of the Commission. Horizontal rules and public registry), C (2005) 2817.

European Commission (2008), Page of the Secretaryship-General dedicated to the expert groups:

http://ec.europa.eu/transparency/regexpert/index.cfm, visited on 1 September 2008

Dauvin P., Siméant J. (2004), ONG et humanitaire (NGO and humanitarianism), Paris, l'Harmattan

Eichener V. (1992), Social dumping or Innovative regulations? Processes and Outcomes of European Decision-Making in the Sector of Health and Safety at Work Harmonisation, European University Institute Working Paper, 92/98. Florence

Eymeri-Douzans J.-M. (2008), «Faire l'expert pour la Commission européenne (Working as an expert for the European Commission). Essai d'auto-analyse d'une pratique ambiguë (Selfanalysing essay on an ambiguous practice)», Text for the colloquium entitled «Europe : object, agent and socialisation stake», ENS-LSH, Lyon, 9 and 10 October 2008 (to be published)

Fouilleux E., Maillard (de) J., Smith A. (2004), «Les groupes de travail du Conseil : nerf de la production des politiques européennes ? (The working groups of the Council; the sinews of the production of the European policies?», in Lequesne C., Surel Y. (dir), L'institutionnalisation de l'Union européenne, Paris, Presses de Sciences Po

Georgakakis D., de Lassalle M. (2004), «Les directeurs généraux de la Commission. Premiers éléments d'une enquête prosopographique » (The Directors-General of the Commission. First elements of a prosopographic investigation), Sociological observations, $27 \& 28$

Georgakakis D., de Lassalle M. (2007), «Les très hauts fonctionnaires de la Commission européenne : genèse et structure d'un capital institutionnel européen » (The very top officials of the European Commission : genesis and structure of an European institutional capital), Acts of the Research in Social Sciences, 166-167

Gornitzka A., Sverdrup U. (2008a), «Who are the experts ? The informational basis of EU decision-making », Arena Working Paper, Center for European Studies, University of Oslo, http://www.arena.uio.no/publications/working-papers2008/papers/wp08_14.pdf 
Gornitzka A., Sverdrup U. (2008b), «Who Consults? The Configuration of Expert Groups in the European Union », West European Politics 31(4)

Hauray B. (2006), L'Europe du médicament. Politique, expertise, intérêts privés (Medication in Europe. Policy, expertise, private interests), Paris, Presses de Science-Po

Krapohl S. (2003), «Risk regulation between interests and expertise: the case of BSE », Journal of European Public Policy, 10(2), 189-207

Juncos A. E., Pomorska K. (2006), «Playing the Brussels game: Strategic socialisation in the CFSP Council Working Groups », European Integration On Line Paper, 10

Lewis J. (2005), « The Janus Face of Brussels: Socialization and Everyday Decision Making in the European Union », International Organization, 59

Larsson T. (2003), Pre-cooking - the world of expert groups in the European Union, A report for the Swedish Finance Minister

Larsson T. Murk J. (2007), «The Commission's expert groups », in Christiansen Thomas, Larsson Torbjörn and Schaeffer Günter (eds.), The Role of Committees in the Policy Process of the European Union, London, Ashgate

Maillard (de) J., Robert C. (2008), «Gouvernement par comités » (Committee-based government), in Belot C., Magnette P., Saurugger S. (dir.), Science politique de l'Union européenne, Paris, Economica

Memmi D. (1989), «Savants et maîtres à penser. La fabrication d'une morale de la procréation artificielle » (Scientists and mentors. Forming the morals of artificial procreation), Acts of the Research in Social Sciences, 76-77

Michel H. (2007), « La 'société civile' dans la 'gouvernance européenne'. Eléments pour une sociologie d'une catégorie politique » («Civil society » in « European governance”. Element for a sociology of a political category), Acts of the Research in Social Sciences, 166-167, 3037

Padioleau J.-G. (2000), «La gouvernance ou comment s'en débarasser. Stratégies de corruption » (Governance or how to get rid of it. Corruption strategies), Le Banquet, 5

Peuziat J.-P., 2005, La politique régionale de l'Union européenne, entre expertise et réforme (The regional policy of the European Union, between expertise and reform), Paris, L'Harmattan

Pitkin H. (1967), The Concept of Representation, Berkeley, University of California Press

Robert C. (2005), «Doing politics and pretending not to. The Commission's role in distributing aid to Eastern Europe », in A. Smith (ed.), Politics and the European Commission. Actors, interdependence, legitimacy, London, Routledge

Robert C. (2008a), « De la représentativité de l'expertise à la représentation par l'expertise. Les usages et enjeux d'une «démocratisation» de l'expertise européenne » (From representativity of expertise to representation by expertise. Usages and issues of a "democratisation" of the European expertise.) a text presented at the colloquium on "the selection of the actors and of the instruments of public action", IEP of Lyon, July 2008.

Robert C. (2008b), «Expertise et action publique » (Expertise and public action), in Borraz O., Guiraudon V. (dir), Politiques publiques, vol.1, Paris, Presses de Science Po

Robert C. (2009a), «Entre expertise et consultation : les légitimités paradoxales des groupes d'experts européens » (Between expertise and consulting; the paradoxical legitimacies of the 
European Expert Groups), in Camau M., Massardier G. (dir), Démocraties et autoritarismes. Fragmentations et hybridations des régimes, Paris, Karthala

Robert C. (2009b), « Devenir 'expert' auprès de la Commission européenne : une question de savoir-faire ? Sens du jeu institutionnel et socialisation politique » (Becoming an 'expert' before the European Commission: a question of know-how? Sense of the institutional game and political socialisation), in Michel H., Robert C. (dir) (2009), La fabrique des européens. L'Europe : objet, agent et enjeu de socialisation (The Europe factory. Europe : object, agent and socialisation stake), Presses universitaires de Strasbourg, (to be published)

Vasallos Y. (2008), Secrecy and corporate dominance. A study on European Commission Expert Groups, Brusels, Alter EU (Available on www.alter.eu.org)

Wagner A.-C. (2004), «Syndicalistes européens. Les conditions sociales et institutionnelles de l'internationalisation des militants syndicaux » (European union activists. The social and institutional conditions of the internationalisation of union activists), Acts of the Research in Social Sciences, 155

Wagner A.-C. (2006), «Les représentants de la C.E.S. entre militantisme et expertise des affaires européennes » (The representatives of the E.C.S. between activism and expertise in European affairs) in Hélène Michel (dir.), Lobbying et lobbyistes en Europe (Lobbying and lobbyists in Europe), Strasbourg, PUS, 2006 